\title{
Can flipped learning enhance adolescents' motivation in physical education? An intervention study
}

\author{
Ove Østerlie* \\ Department of Teacher Education, Faculty of Social and Educational Sciences, \\ NTNU Norwegian University of Science and Technology, Trondheim, Norway
}

\begin{abstract}
Objective: To be engaged and successful in learning in physical education (PE), students needs to be motivated. The purpose of this study was to examine the impact of flipped learning (FL) on adolescents' motivation to participate in PE.

Methods: Students in Grades 8-11 ( $N=338,45.3 \%$ girls $)$ were recruited from 6 secondary and upper-secondary schools from three different counties in Norway in the spring semester of 2016. Following a quasi-experimental design with a control group, data were gathered using an expectancy-value questionnaire (EVQ).

Results: Mean results revealed that FL has a significant impact on adolescents' expectancy beliefs and attainment values regarding participation in PE. All significant changes in the intervention group could be explained by gender.

Conclusion: In an expectancy-value perspective, FL positively influences the motivation of adolescents, especially that of girls, to participate in PE. Therefore, FL can be used to enhance adolescents' motivation to participate in PE.
\end{abstract}

Keywords: Expectancy beliefs; subjective task values; expectancy-value questionnaire; flipped classrooms; blended learning; physical education (PE)

Received: June, 2017; Accepted: December, 2017; Published: January, 2018

\section{Introduction}

As part of a research project on how flipped learning (FL) affects adolescents' motivation to participate in physical education (PE) and their learning outcomes in PE, this article describes how FL affects motivation from an expectancy-value perspective. The study reported here took a student's perspective in analysing self-reported motivation to engage in PE. In what follows, after this introduction's discussion of

*Correspondence: Ove Østerlie, NTNU, ILU Lysholm, Postboks 8900, NO-7491 Trondheim, Norway. E-mail: ove.osterlie@ntnu.no

(C) 2018 O. Østerlie. This is an Open Access article distributed under the terms of the Creative Commons Attribution 4.0 International License (http://creativecommons.org/licenses/by/4.0/), allowing third parties to copy and redistribute the material in any medium or format and to remix, transform, and build upon the material for any purpose, even commercially, provided the original work is properly cited and states its license. 


\section{O. Østerlie}

key concepts, the article describes the study's methods, presents the results of the research, discusses the implications of the results and closes with a conclusion and outline of recommendations for further research.

Worldwide, children tend to engage in sedentary lifestyles and thus insufficient levels of physical activity (World Health Organization [WHO], 2010, 2016). PE plays an important role in the constellation of factors that affect levels of physical activity among children (Cheval, Courvoisier \& Chanal, 2016; Cooper et al., 2016; Fröberg, Raustorp, Pagels, Larsson, \& Boldemann, 2017). Although motivation is strongly linked to learning in school (Hattie, 2009), students' motivation to participate actively in PE is low and declines as students age (Gao, Lee \& Harrison, 2008; Säfvenbom, Haugen \& Bulie, 2014), especially among girls (Säfvenbom et al., 2014; Thomas, Lee \& Thomas, 2008). For the first time, in 2012 the Norwegian national curriculum for PE recognised the concept of motivation by stating that, as a school subject, PE should

“... help pupils acquire knowledge about exercise and training, lifestyle and health, and motivate them to have an active life and continue physical training into adulthood." (Norwegian Directorate for Education and Training, 2015, p. 2). Such recognition calls for added focus on motivation to participate in PE among children and adolescents and how teachers can support and improve their motivation.

The WHO (2016) promotes the exploration of innovative approaches to promote physical activity among adolescents in their member states. In general, society benefits from $\mathrm{PE}$ given its contributions to encouraging students to actively participate in PE and engage in active, healthy lifestyles throughout their lives. However, to realise that potential, PE as a subject needs to develop content that is more relevant to its aims (Arnesen, Nilsen \& Leirhaug, 2013; Moen, Westlie, Brattli, Bjørke \&Vaktskjold, 2015). For instance, the content of PE should encompass a variety of activities and skills (Rikard \& Banville, 2006), convey knowledge about physical activity, mobility and movement, and promote teamwork and competitive aspects of sport so that all children and adolescents can enjoy physical activity and gain from its health-related benefits, regardless of their preferences or previous experience (WHO, 2016). However, the subject and its curriculum continue to endorse 'sportified' PE (Vlieghe, 2013) that seems to privilege boys (Engelsrud, 2015; Flintoff \& Scraton, 2006; Klomsten, 2013; Klomsten, Marsh \& Skaalvik, 2005; Valley \& Graber, 2014) and adolescents who participate in competitive sports outside school (Säfvenbom et al., 2014). Since motivation has declined as the use of traditional teaching methods persists, exploring other methods of teaching to expand the PE teacher's toolbox is both timely and necessary.

\section{Flipped learning}

FL is a pedagogical approach in which direct instruction gradually shifts from a group learning space to an individual learning space, which then becomes a dynamic, interactive learning environment in which educators guide students as they apply concepts and engage creatively in the subject matter (Flipped Learning Network [FLN], 2014a). 
Using FL can help teachers approach their subjects from more holistic perspectives (Segolsson \& Bäcklund, 2016). Moreover, as observed across a range of subjects and student age groups, learning outcomes and levels of satisfaction have improved among students whose teachers have used FL (FLN, 2014b; Zainuddin \& Halili, 2016). In elementary schools, FL can cultivate better problem-solving skills among students (Segolsson \& Bäcklund, 2016) and enhance students' self-efficacy and learning strategies (Lai \& Hwang, 2016). At the university level, when classes meet students' preferences for pre-class preparation via video instead of text-based modes (Long, Logan \&Waugh, 2016), their engagement in coursework has improved (Lumpkin \& Achen, 2015; Thompson \& Ayers, 2015). FL can also benefit students with low performance as well as girls and women (Gross, Pietri, Anderson, MoyanoCamihort \& Graham, 2015). However, given the overly broad variety of interventions and research designs in FL, the effects (Bishop \& Verleger, 2013) and effectiveness (Abeysekera \& Dawson, 2015) of specific methods require additional investigation.

\section{Flipped learning in physical education}

In PE, FL could involve, for example, students' preparing for class at home by watching a video about the next class topic-for instance, strength training. In FL, the video would consist of the teacher's explanation and demonstration of strength training, as well as an explanation of physiological changes that occur when you become stronger and how the changes affect personal health. Thereafter, the video would likely shift to explaining the content and activities of the next class and pose questions about the content of the video. At the beginning of class, students would therefore already know what they have to do for that class and even commence activities without needing their teacher's instructions. During the lesson, students could talk about strength training in light of content presented in the video both among themselves and with the teacher. The class would likely conclude with students' presenting explanation of the key topics related to strength training.

Killian, Trendowski, and Woods (2016) have reported that flipping content in university PE classes affords positive outcomes because it expands time spent on practical activities and extends feedback from instructors. In secondary-school PE classes, FL can benefit individualisation when applied to teach learning skills during orientation activities (García, Castro \& Morales, 2015). In other research, despite PE teachers' use of an FL model to introduce students to the rules of unfamiliar games (Bergmann \& Sams, 2014), evidence of the model's impact remains unclear, as does its effects. Nevertheless, in general, researchers have called for more innovative teaching methods in PE (Zhang, 2016), and FL continues to rank among the possible responses (Zainuddin \& Halili, 2016; Østerlie, 2016).

Several pedagogical modes that focus on student-centred activities have gradually replaced the traditional so-called 'demonstrate-explain-practice' method in PE. Those modes (e.g. sport education, teaching games for understanding, cooperative 


\section{O. Østerlie}

learning) all promote interaction and reflection among students during practical PE activities, and studies have investigated those behaviours among teachers and students in PE classes as they work together (e.g. Darnis \& Lafont, 2015). Although such research has demonstrated positive results in terms of learning outcomes and student-teacher social relationships, additional investigations remain necessary (Barker, Wallhead \& Quennerstedt, 2016).

FL ranks high among teaching modes that promote interaction and more on-topic conversations among students because they arrive better prepared for class with an increased level of knowledge and understanding about the lesson's topic and activities. FL also facilitates student-centred activities (Heinerichs, Pazzaglia \& Gilboy, 2016) because students' preparation before class reduces the time spent on explanation and instruction in the classroom.

\section{Expectancy-value theory}

In educational research, expectancy beliefs (EBs) and subjective task values (STVs) are considered to be important predictors of students' academic performance and behaviour (Eccles, 1983; Eccles \& Wigfield, 1995). From the other direction, students' achievement and performance are directly influenced by their EBs and STVs (Eccles, 1983; Eccles \& Wigfield, 2002; Wigfield \& Eccles, 2000). EBs are conceived as broad beliefs about personal competence in a given domain ( $\mathrm{Zhu}$, Sun, Chen \& Ennis, 2012), among which expectancy of success refers to beliefs about how well the person will perform on a given task. Expectancy of success functions as an independent motivational factor independent of the motivational factor of STVs, as Eccles \& Wigfield (1995) have indicated. According to Eccles (1983), there are four task values attached to a certain domain: attainment value (AV), intrinsic and interest value (IV), utility value (UV) and cost. AV is a person's perceived importance of doing well on a task; IV is the level of enjoyment that a person perceives doing a task will offer; and UV is how the perceived usefulness in doing a task relates to current and future personal goals (Eccles \&Wigfield, 2002). Arguably, EBs and STVs bear a more direct impact on learning behaviour and achievement than other motivation constructs, including self-efficacy and achievement goal orientation (A. Chen, Martin, Ennis \& Sun, 2008).

\section{Expectancy-value theory and physical education}

Expectancy-value theory is an important theoretical lens with which to examine and understand student learning and motivation in PE (Gao, 2009; Zhu et al., 2012). Motivation is associated with students' intentions to perform, engage in and participate in PE (Xiang, McBride, \& Bruene, 2004, 2006), but not necessarily with learning achievement (Zhu \& Chen, 2010). Regarding gender-based differences in EBs and STVs in PE, boys tend to have higher EBs than girls, although the same 
differences do not characterise their STVs (Gao, 2009; Xiang, McBride \& Bruene, 2004; Xiang et al., 2006; Xiang, McBride, Guan \& Solmon, 2003).

Research has shown that students' general expectancy-value motivation declines with age throughout their elementary, middle and secondary school career in academic subjects, especially PE, for both boys and girls (Eccles, Wigfield, Harold, \& Blumenfeld, 1993; Jacobs, Lanza, Osgood, Eccles \& Wigfield, 2002; Xiang et al., 2006; Xiang, McBride \& Guan, 2004). Although age has recently been observed to explain STVs, it has not been shown to affect EBs. Moreover, in primary and middle school, although STVs decline, EBs do not (Zhu \& Chen, 2010; Zhu et al., 2012).

Identifying adolescents' motivational dynamics in relation to their participation in PE might be a vital resource for facilitating PE learning and preventing further declines in students' motivation. In response, the goal of the study reported here was to determine whether using FL as a teaching method affects student motivation to participate in PE based on their EBs and STVs for the subject. To that end, two research questions emerged:

Q1: Can flipped learning enhance adolescents' expectancy beliefs in physical education?

Q2: Can flipped learning enhance adolescents' subjective task values in physical education?

\section{Methods}

\section{Participants}

Students $(N=338,92.9 \%$ of 364 invited $)$ from six different secondary and uppersecondary schools were recruited to participate in present study. Twenty random schools belonging to three different regions in Norway were requested to participate by an e-mail to their respective managers resulting in participation of five schools. One school was included by their own request. The six schools that participated represented both rural and central communities with a normal distribution of immigrants and social status.

\section{Demographic variables}

Self-reported information on sex, date of birth and name was obtained from the expectancy-value questionnaire (EVQ) to characterise the sample. Girls $(n=153)$ had a mean age of 15.26 years $(S D=1.3)$, whereas boys $(n=185)$ had a mean age of 15.01 years $(S D=1.12)$. Participants were from four different levels in the Norwegian school system: the three grades of secondary school and the initial grade in upper-secondary school - that is, Grade $8(n=114)$, Grade $9(n=101)$, Grade 10 $(n=38)$ and VG1 $(n=85)$. The students' academic marks (girls: 4.45 , boys: 4.48$)$ during the same semester reflected the national average for Grade 10 (girls: 4.5, boys: 4.6), according to Statistics Norway (2016). 


\section{O. Østerlie}

\section{Research design}

An intervention designed as a quasi-experimental randomised trial with a control group was conducted during a 3-week period during the 2016 spring semester. Since different classes were used in the intervention and compared with control groups, the experiment posed the possibility of selection bias, but also afforded the advantage of comparing naturally occurring events (Hartas, 2010).

Three learning resources dealing with endurance, strength and coordination were used, each of which consisted of a video assigned to students to watch as homework before class, an in-class lesson plan that the PE teacher followed and a teacher's guide. To maximise equivalence among the classes all teachers were instructed by the researcher, by telephone, regarding how to conduct the different activities.

The videos lasted approximately 12 minutes each, which was well within the suggested length for FL videos (Long et al., 2016), and were published on a digital learning platform. Each video gave a thorough, but easily understandable introduction to the content of the in-class topic. For example, when strength was the weekly topic, the video explained strength in an age-appropriate way by discussing why strength benefits personal health, what happens in the body when strength is gained and how to train for strength. Each video ended with a summary of the content of the next class. Short quizzes embedded in the videos were used to enhance students' motivation to continue watching and to deepen their understanding, as suggested by Long et al. (2016) and Frydenberg (2012). The research group and the teachers could view statistics on the platform to monitor which students have watched which videos and their answers on the corresponding quizzes.

Since no framework for FL environments has been established to date (Bishop \& Verleger, 2013), the design of the study's FL environment followed the recommendations of Kim, Kim, Khera, and Getman (2014), who defined nine principles for flipped classrooms and the FLIPPED model (Y. Chen, Wang, Kinshuk \& Chen, 2014). The content in practical lessons were game-based activities with few parallels to sport but instead a focus on enjoyment and cooperation during PE. Topics for discussions between students and between the teacher and students were encouraged and increasingly held as the teacher spent less time explaining and became freer to walk among the students. Learning goals in the practical class about endurance included being physically active to develop the body and improve health, talking about endurance training and talking about the connection between endurance and health. In the other two practical classes, the aims were similar but with a different topic and derived from the national curriculum in PE after Grade 10 (Norwegian Directorate for Education and Training, 2015).

Participating classes were randomly divided into two categories. The intervention group $(n=141)$ had access to the videos as homework before coming to class, and the control group $(n=197)$ was subjected to the same practical class as the 
intervention group. To represent the conventional methods of conducting PE classes in Norway as realistically as possible, some of the control groups received a summary of the class topic and of what the videos watched in the intervention groups explained, delivered orally by the PE teacher at the beginning of each PE class and typically lasting about 5 minutes. Some control groups conducted the practical class without any oral explanation of the topic. Both the intervention and control groups performed the same practical activities in class. The control groups were educated during the intervention period according to the traditional way of conducting PE classes in Norway, which ensured that the sole difference was that the intervention group had access to the videos for preparation before class. The control group was not granted such access. As research has shown, although the link between the video content and content of in-class activities is essential to success in FL environments, it is often overlooked (Long et al., 2016). In response, the videos and lesson plan were produced by the researcher, not each individual teacher.

Before the intervention commenced (T1) and at its conclusion (T2), students' motivation for participating in PE was measured with an EVQ. The students' PE teachers administered and collected the self-report questionnaires as instructed by the researcher. The study was reported to the Norwegian Centre for Research Data (project no. 47604).

\section{Variables and measures}

Expectancy-value constructs: The EVQ consists of 11 items on four sub-scales. Five items measure EBs and six measure STVs on three sub-scales: AV, IV and UV (Zhu et al., 2012). Responses to all items are submitted on a 5-point Likert scale (1 = not important, 5 = very important). A sample item used to measure student AV is, 'How important do you think PE is for you?'

The EVQ measures students' EBs and STVs of the domain content and can be used to measure expectancy-value constructs in PE for both middle-school and elementary students (Zhu et al., 2012) with good construct validity and internal reliability (Zhu et al., 2012). It has also shown satisfactory validity and reliability in measuring EBs and STVs for PE among Norwegian adolescents (Østerlie, Løhre \& Haugan, in press).

\section{Data reduction}

Responses to items on the EVQ were entered into the Statistical Package for the Social Sciences version 24 and reduced into EBs and STVs dimensions (i.e. AV, IV and UV). Analysis was performed both on the EVQ as a two-dimensional (i.e. EB and STV) and four-dimensional reduction (i.e. EB, AV, IV and UV), since the dimensionality of the EVQ has been shown to be unclear (Østerlie et al., in press). 


\section{O. Osterlie}

\section{Data analysis}

Initially, the dataset was cleaned and screened for missing data, out-of-range values, outliers and sample distribution normality. A missing values analysis was performed on the dataset, and the result of Little's MCAR test was not significant when all items were tested together $\left(\chi^{2}(520)=511.94, p=.161\right)$. Since each item had between 7.4 and $14.5 \%$ of data missing, the missing values, as unneglectable values, could not be replaced at a limit of $2 \%$. Since data were assumed to be missing completely at random by Little's test, analysis was continued. Gaps in the data perhaps stemmed from the fact that the T1 and T2 forms were completed at school on specific dates. Absence from school would have prompted a lack of response from some students at either T1 or T2. Formal normality tests showed values of skewness and kurtosis within the normal range for all constructs $(<|1.4|$ ), with a normal range of $<|2|$ (West, Finch \& Curran, 1995). Accordingly, data were regarded fit for testing and comparing means. Any $p$ value less than .05 was considered to be statistically significant.

A paired samples $t$ test, with list-wise exclusion, was used to identify any significant change in mean score from T1 to T2 for both the intervention and control groups and between genders in the intervention group. A $t$ test (i.e. analysis of variance) was used to identify any significant differences between the intervention and control groups at either T1 or at T2 for any dimension of the EVQ. Pearson's correlation coefficient was computed to assess the relationship between the EVQ and the age of students.

\section{Results}

\section{Results from the EVQ}

Table 1 presents descriptive statistics for each dimension of the EVQ.

The paired-sample $t$ test demonstrated a significant increase from T1 to T2 for the EB construct $(p=.020,95 \% \mathrm{CI}[0.20,0.02])$ and the AV construct $(p=.034,95 \%$ CI $[0.26,0.01])$ in the intervention group. No significant changes emerged in the control group in any of the EVQ constructs.

Table 1. Descriptive statistics for each variable of the expectancy-value questionnaire (EVQ) with $\mathrm{T} 1$ values and, in parentheses, $\mathrm{T} 2$ values

\begin{tabular}{lcccc}
\hline \multirow{2}{*}{ EVQ dimensions } & \multicolumn{2}{c}{ Intervention group $(n=141)$} & \multicolumn{2}{c}{ Control group $(n=197)$} \\
\cline { 2 - 5 } & \multicolumn{1}{c}{$M$} & $S D$ & $M$ & $S D$ \\
\hline EB & $4.01(4.18) \mathrm{a}$ & $0.73(0.58)$ & $3.85(3.88 \mathrm{bb})$ & $0.84(0.87)$ \\
STV & $3.84(3.95)$ & $0.80(0.73)$ & $3.59 \mathrm{~b}(3.66 \mathrm{bb})$ & $0.90(0.85)$ \\
AV & $3.90(4.07) \mathrm{a}$ & $0.89(0.83)$ & $3.59 \mathrm{bb}(3.72 \mathrm{bb})$ & $1.08(1.02)$ \\
IV & $3.90(3.96)$ & $0.92(0.79)$ & $3.64 \mathrm{~b}(3.71 \mathrm{~b})$ & $1.05(0.90)$ \\
UV & $3.76(3.81)$ & $0.91(0.87)$ & $3.47 \mathrm{~b}(3.59 \mathrm{~b})$ & $1.03(0.96)$ \\
\hline
\end{tabular}

Note. $\mathrm{T} 1$ = measurement before intervention period; $\mathrm{T} 2=$ measurement after intervention period; EB = Expectancy belief; $\mathrm{STV}=$ subjective task value; $\mathrm{AV}=$ attainment value; $\mathrm{IV}=$ intrinsic value; $\mathrm{UV}=$ utility value $\mathrm{a}=$ significant change from T1 to T2 $(p<.05) ; \mathrm{b}=$ significant difference between the intervention group and the control group $(p<.05) ; \mathrm{bb}=$ significant difference between the intervention group and the control group $(p<.01)$. 
Table 2. Descriptive statistics for each variable of the expectancy-value questionnaire (EVQ) in the intervention group by gender with $\mathrm{T} 1$ values and, in parentheses, $\mathrm{T} 2$ values

\begin{tabular}{lcccccc}
\hline \multirow{2}{*}{ EVQ dimensions } & \multicolumn{4}{c}{ Girls } & \multicolumn{4}{c}{ Boys } \\
\cline { 2 - 7 } & $n$ & $M$ & $S D$ & $n$ & $M$ & $S D$ \\
\hline EB & 44 & $3.88(4.03) \mathrm{a}$ & $0.73(0.57)$ & 66 & $4.15 \mathrm{~b}(4.23 \mathrm{~b})$ & $0.67(0.56)$ \\
STV & 42 & $3.82(3.92)$ & $0.87(0.73)$ & 65 & $3.89(3.90)$ & $0.77(0.75)$ \\
AV & 45 & $3.90(4.11) \mathrm{a}$ & $0.95(0.76)$ & 68 & $3.90(3.98)$ & $0.86(0.85)$ \\
IV & 46 & $3.86(3.96)$ & $0.95(0.81)$ & 69 & $4.00(3.98)$ & $0.91(0.80)$ \\
UV & 43 & $3.77(3.74)$ & $1.00(0.90)$ & 67 & $3.86(3.81)$ & $0.84(0.89)$ \\
\hline
\end{tabular}

Note. $\mathrm{T} 1=$ measurement before intervention period; $\mathrm{T} 2=$ measurement after intervention period; $\mathrm{EB}=$ expectancy belief; $\mathrm{STV}=$ subjective task value; $\mathrm{AV}=$ attainment value; $\mathrm{IV}=$ intrinsic value; $\mathrm{UV}=$ utility valuea $=$ significant change from $\mathrm{T} 1$ to $\mathrm{T} 2(p<.05) ; \mathrm{b}=$ significant difference between girls and boys $(p<.05)$

In the intervention group, gender-based differences were clear, as presented in Table 2 .

The paired-sample $t$ test revealed a significant increase from T1 to T2 for the EB construct $(p=.045,95 \% \mathrm{CI}[0.30,0.00])$ and the AV construct $(p=.016,95 \% \mathrm{CI}$ $[0.37,0.04])$ among girls. No significant changes emerged among boys in any of the EVQ constructs. The boys had significantly higher scores on the EB construct, but not on the other constructs, at both $\mathrm{T} 1$ and $\mathrm{T} 2$.

Since several studies have found that EB and STV decline with age, that dynamic was also tested at T1 with the results of a Pearson's correlation coefficient test with two-tailed, pairwise exclusion, the results of which showed that age correlated with STVs $(n=286, r=-.251, p<.001)$, but not EBs $(n=302, r=-.032, p=.584)$.

\section{Discussion}

Flipped learning and students' expectancy beliefs about physical education Results show that FL had a significant impact on students' EBs. In the intervention group, that change emerged among girls, but to only a weakly significant degree. Similar to previous research (e.g. Gao, 2009), initial EBs were on the same level and demonstrated the same variations in gender. Boys had significantly higher EBs than girls both at $\mathrm{T} 1$ and $\mathrm{T} 2$. Using the definition of expectancies as specific beliefs that individuals have regarding their success on tasks that they will perform sooner or later in the future (Eccles \& Wigfield, 2002) in traditional PE settings, girls have shown lower final grades (Statistics Norway, 2016), less motivation and less satisfaction (Klomsten et al., 2005; Stormoen, Urke, Tjomsland, Wold \& Diseth, 2016; Säfvenbom et al., 2014).

The intervention included three lessons on endurance, strength and coordination. Practical lessons involved activities with few elements from sports or competition. Gender-based differences often appear in conventionally gendered activities in which boys have been more likely to feel competent about and perform better on tasks such as football and basketball than girls have, whereas girls have tended to 


\section{O. Østerlie}

feel more competent and perform better on tasks such as dance and gymnastics than boys have (Xiang et al., 2006). However, those trends alone cannot explain the difference detected in the study reported here, since both the intervention and control groups performed the same activities.

The chief difference and thus the chief contributor to the effect on EBs using FL seems to be the videos assigned as homework, which conveyed information about the activities in the upcoming class. In class, such content was briefly repeated by the teacher and discussed among students. The shift in amount of information prior to class, being somewhat different than that of their typical experiences, can explain why girls showed significantly increased EBs, but not the boys. The intervention period, having included only three lessons, could have prompted possible bias, which bears consideration during the interpretation of results. Would this shift among girls' expectancy beliefs stabilise, increase or decrease if FL were used over a longer period of time? At least one study has demonstrated the importance of information to students, who are more likely to engage in class when they understand and believe in the subject matter (Dyson, 2006).

$\mathrm{PE}$ is a subject in which a lack of competence is far more visible than in most other school subjects, since the primary tool in the learning process is the body. That circumstance might explain why girls have lower EBs, as the content in PE is culturally assumed to be somewhat more beneficial to boys than to girls (e.g. Engelsrud, 2015). Regarding mathematics education, Lai and Hwang (2016) found that FL enhanced elementary-school students' self-efficacy by promoting more self-regulated learning processes. That result implies that PE curriculum could also be more directed at boys than girls compared to mathematics, since those authors did not detect similar differences by gender. By extension, the finding could explain why girls benefitted more from FL in PE than boys did in the study reported here. When individuals are informed about how to perform a task, they tend to have more confidence that they can succeed in performing the task. Historically, girls have been seen as problematic in PE because they do not engage as much as boys do (Enright \& O'Sullivan, 2010). Of course, researchers have increasingly challenged that discourse of blame, and the study reported here supports the idea that teachers need to reconsider PE content and its delivery more than simply demanding girls to change.

Age does not seem to explain students' EBs in PE. Empirical results show that EBs did not negatively correlate with age to a significant degree. That finding supports $\mathrm{Zhu}$ et al.'s (2012) and Gao's (2009) results among elementary- and middle-school students. Furthermore, the rather low $n$ among students in Grade 10 could have prompted possible bias, which bears consideration during the interpretation of results.

\section{Flipped learning and students' subjective task values of physical education}

Interpreting results from the EVQ can follow one of two approaches - namely, imposing either a two- or four-dimensional construct - since its dimensionality is somewhat blurred (Xiang et al., 2003; Østerlie et al., in press). 
When comparing the intervention group to the control group, significant differences regarding STVs as a dimension were not observed, which corroborates earlier findings among middle-school students (Gao, 2009; Xiang, McBride \& Bruene, 2004; Xiang et al., 2006; Xiang et al., 2003). When considering the different dimensions involving STVs, a significant, albeit weak, difference regarding the students' attainment value for PE surfaced, but only among girls. Attainment value is a person's perceived importance of doing well on a task as it relates to how their self-conception and ideals inform their competence in the domain (Wigfield, 1994).

Considering the videos' content the importance of being familiar with the context of activities conducted, knowledge about the curriculum and activities, as well as recognised competence seems to be a motivator for participation. These findings align with earlier research that has stressed the importance of emphasising the value of PE by informing students about the benefits of each PE activity prior to its performance (Gao et al., 2008) can greatly motivate students to participate in PE, especially girls (Inchley, Kirby \& Currie, 2011). Since those factors seem to positively affect gender variations in PE, FL is arguably an effective facilitator of that process. Previous research has unsurprisingly shown inconsistency in conclusions about gender-based differences regarding STVs (Gao et al., 2008). Gao (2009) has reported gender-based differences regarding interest, but not regarding usefulness and importance, whereas no gender-based differences regarding task values have been observed in other studies (e.g. Xiang et al., 2006). Such inconsistency underscores the need for more research on gender-based differences and student motivation in PE in elementary, middle and secondary schools.

Age seems to explain STVs in PE, which declined over the course of secondary school in the results. That finding corroborates the results of Wigfield et al. (1997), Zhu et al. (2012) and Zhu and Chen (2010), who detected the same trend among children in elementary and middle school. That decline also emerged in a 12-year longitudinal study (Jacobs et al., 2002). As expectancy-value theory describes (Wigfield \& Eccles, 2000), it is exceptionally difficult for students to value the content of a subject without deeper learning. The more explicitly that the values of an assignment are explained, the more likely students will become engaged in the assignment and remain motivated to further their study of the content area (Paris, Lipson \& Wixson, 1983; Wigfield, 2000). Accordingly, increased focus on in-depth learning in PE is a valuable approach and should include knowledge, physical literacy and social skills. FL is a tool that PE teachers can use to increase the depth of learning because it requires students to prepare before class by watching curriculum-related content, their knowledge of which is further constructed in class with other students and their teacher, which could contribute to curbing the decline in students' valuations of PE.

\section{Strengths and limitations}

The sample of 338 adolescents (response rate 93\%) from six schools in three counties in Norway was a major strength of the study. The sample represented a diversity 


\section{O. Østerlie}

of locations in both urban and rural areas, thereby reflecting the general adolescent population in Norway. Moreover, the students' semester marks corresponded with the national average grade for the actual semester, which indicated that the sample did not differ from the general Norwegian adolescent population in terms of academic performance. Plus, PE teachers administered data collection at the start of a PE lesson, which ensured participant anonymity and enough time for participants to complete the questionnaire. The procedure of using a familiar questionnaire administrator in familiar surroundings contributed to students' feeling comfortable in the assessment situation and, in turn, generated reliable data, which was another strength of the study.

Nevertheless, some limitations should be taken into consideration. Since the sample included adolescents 13-17 years old, its results cannot be generalised to younger children or older adolescents. The intervention period, which spanned only three sessions, and the low $n$ among Grade 10 students and subgroups (Table 2) could have been other limitations. Lastly, the study did not present strong significance in much of the statistical results, and when interpreting interviews from such a small sample, generalisability must be considered as a limitation.

\section{Conclusions}

The study reported here has shown that flipped learning (FL) increases expectancybeliefs and attainment values among students regarding physical education. FL can thus benefit adolescents' motivation to participate in PE. As discussed, FL seems to benefit girls more than boys in PE settings and can therefore be an important contributor for equalising gender-based differences in PE. The study has provided additionally, an observed decline in STVs, but not in EBs, among students from elementary to secondary school. In sum, FL is an appropriate pedagogical approach in PE for deeper learning and can contribute to halting the decline in children's valuation of PE.

Future research should further identify and examine FL practices and the impact that the method can have in PE, both in a broader context and longitudinally. Furthermore, research on both general motivation in PE and gender-based differences in that motivation is necessary. Since motivation is linked to learning and a strong predictor of behaviour, more research on how to preserve and enhance children's motivation to participate in PE is important.

\section{Conflict of interest}

I declare that I have had no conflicts of interest in conducting or publishing my research.

\section{References}

Abeysekera, L. \& Dawson, P. (2015). Motivation and cognitive load in the flipped classroom: Definition, rationale and a call for research. Higher Education Research and Development, 34, 1-14. https://doi.org/10.1080 /07294360.2014.934336 


\section{Can flipped learning enhance adolescents' motivation in physical education?}

Arnesen, T. E., Nilsen, A. K. \& Leirhaug, P. E. (2013). "Den læreplanen som ikkje kan tilpassast mi undervisning, finst ikkje.": Vurdering og undervisning i kroppsøving etter kunnskapsløftet. Tidsskriftet FoU $i$ praksis, 7, 9-32.

Barker, D., Wallhead, T. \& Quennerstedt, M. (2016). Student learning through interaction in physical education. European Physical Education Review, 23, 273-278. https://doi.org/10.1177/1356336X16640235

Bergmann, J. \& Sams, A. (2014). Flipped learning : Gateway to student engagement. Eugene, Or: International Society for Technology in Education.

Bishop, J. L. \&Verleger, M. A. (2013). The flipped classroom: A survey of the research. Paper presented at the ASEE National Conference Proceedings, Atlanta, GA.

Chen, A., Martin, R., Ennis, C. D. \& Sun, H. (2008). Content specificity of expectancy beliefs and task values in elementary physical education. Research Quarterly for Exercise and Sport, 79, 195-208. https://doi.org/1 0.1080/02701367.2008.10599483

Chen, Y., Wang, Y., Kinshuk, N.-S. \& Chen, N.-S. (2014). Is FLIP enough? Or should we use the FLIPPED model instead? Computers $\mathcal{E}$ Education, 79, 16-27. https://doi.org/10.1016/j.compedu.2014.07.004

Cheval, B., Courvoisier, D. S. \& Chanal, J. (2016). Developmental trajectories of physical activity during elementary school physical education. Preventive medicine, 87, 170-174. https://doi.org/10.1016/j. ypmed.2016.02.043

Cooper, K. H., Greenberg, J. D., Castelli, D. M., Barton, M., Martin, S. B. \& Morrow Jr, J. R. (2016). Implementing policies to enhance physical education and physical activity in schools. Research Quarterly for Exercise and Sport, 87, 133-140. https://doi.org/10.1080/02701367.2016.1164009

Darnis, F. \& Lafont, L. (2015). Cooperative learning and dyadic interactions: Two modes of knowledge construction in socio-constructivist settings for team-sport teaching. Physical Education and Sport Pedagogy, 20, 459-473. https://doi.org/10.1080/17408989.2013.803528

Dyson, B. (2006). Students' perspectives of physical education. In D. Kirk, D. MacDonald, \& M. O'Sullivan (Eds.), Handbook of physical education (pp. 326-346). London, UK: Sage.

Eccles, J. S. (1983). Expectancies, values, and academic behaviors. In J. T. Spence (Ed.), Achievement and achievement motives : psychological and sociological approaches. San Francisco, CA: Freeman.

Eccles, J. S. \& Wigfield, A. (1995). In the mind of the actor: The structure of adolescent achievement task values and expectancy-related beliefs. Personality and Social Psychology Bulletin, 21(3), 215-225.

Eccles, J. S., \& Wigfield, A. (2002). Motivational beliefs, values, and goals. Annual review of psychology, 53, 109-132.

Eccles, J. S., Wigfield, A., Harold, R. D. \& Blumenfeld, P. (1993). Ontogeny of children's self-perceptions and subjective task values across activity domains during the early elementary school years. Child Development, 64, 830-847.

Engelsrud, G. (2015). Kjønn og inkludering. In Ø. F. Standal \& G. Rugseth (Eds.), Inkluderende kroppsøving (pp. 24-43). Oslo, Norway: Cappelen Damm Akademisk.

Enright, E. \& O'Sullivan, M. (2010). 'Can I do it in my pyjamas?' Negotiating a physical education curriculum with teenage girls. European Physical Education Review, 16, 203-222. https://doi. org/10.1177/1356336X10382967

Flintoff, A. \& Scraton, S. (2006). Girls and physical education. In D. Kirk, D. MacDonald, \& M. O'Sullivan (Eds.), Handbook of physical education (pp. 767-783). London, UK: Sage.

Flipped Learning Network [FLN]. (2014a). Definition of flipped learning. Retrieved from http://flippedlearning.org/domain $/ 46$

Flipped Learning Network [FLN]. (2014b). Extension of a review of flipped learning. Retrieved from http:// flippedlearning.org/domain/46

Frydenberg, M. (2012). Flipping excel. Paper presented at the Information Systems Educators Conference, New Orleans Louisiana, USA.

Fröberg, A., Raustorp, A., Pagels, P., Larsson, C., \& Boldemann, C. (2017). Levels of physical activity during physical education lessons in Sweden. Acta Paediatrica, 106, 135-141. https://doi.org/10.1111/apa.13551

Gao, Z. (2009). Students' motivation, engagement, satisfaction, and cardiorespiratory fitness in physical education. FournalofApplied Sport Psychology, 21,102-115.https://doi.org/10.1080/10413200802582789

Gao, Z., Lee, A. M. \& Harrison, L., Jr. (2008). Understanding students' motivation in sport and physical education: From the expectancy-value model and self-efficacy theory perspectives. Quest, 60, 236-254. https:// doi.org/10.1080/00336297.2008.10483579

García, I. G., Castro, L. N. \& Morales, P. T. (2015). Las flipped classroom a través del smartphone: Efectos de su experimentación en educación física secundaria. Prisma Social: revista de ciencias sociales(15), 296-351. 


\section{O. Østerlie}

Gross, D., Pietri, E. S., Anderson, G., Moyano-Camihort, K. \& Graham, M. J. (2015). Increased preclass preparation underlies student outcome improvement in the flipped classroom. CBE life sciences education, 14, 1-8. https://doi.org/10.1187/cbe.15-02-0040

Hartas, D. (2010). Experimental and quasi-experimental designs in educational research. In D. Hartas (Ed.), Educational research and inquiry: Qualitative and quantitative approaches (pp. 239-256). London, UK: Continuum.

Hattie, J. (2009). Visible learning : A synthesis of over 800 meta-analyses relating to achievement. London, UK: Routledge.

Heinerichs, S., Pazzaglia, G. \& Gilboy, M. B. (2016). Using flipped classroom components in blended courses to maximize student learning. Athletic Training Education fournal, 11, 54-57. https://doi.org/10.4085/110154

Inchley, J., Kirby, J. \& Currie, C. (2011). Longitudinal changes in physical self-perceptions and associations with physical activity during adolescence. Pediatric Exercise Science, 23, 237-249. https://doi.org/10.1123/ pes.23.2.237

Jacobs, J. E., Lanza, S., Osgood, D. W., Eccles, J. S. \& Wigfield, A. (2002). Changes in children's self-competence and values: Gender and domain differences across grades one through twelve. Child Development, 73, 509-527

Killian, C. M., Trendowski, T. N. \& Woods, A. M. (2016, 11.6.2016). Students' perceptions of flipped instruction in a university physical activity course. Paper presented at the 2016 AIESEP International Conference, Laramie, WY, USA.

Kim, M. K., Kim, S. M., Khera, O. \& Getman, J. (2014). The experience of three flipped classrooms in an urban university: an exploration of design principles. The Internet and Higher Education, 22, 37-50. https://doi. $\operatorname{org} / 10.1016 / j$. iheduc.2014.04.003

Klomsten, A.T. (2013). Hvordan organiseres kroppsøvingsfaget i norske skoler: Kjønnsblandet eller kjønnsdelt? Tidsskriftet FoU i praksis, 7(3), 59-82

Klomsten, A. T., Marsh, H. W. \& Skaalvik, E. M. (2005). Adolescents' perceptions of masculine and feminine values in sport and physical education: A study of gender differences. Sex roles, 52, 625-636. https://doi. org/10.1007/s11199-005-3730-x

Lai, C.-L. \& Hwang, G.-J. (2016). A self-regulated flipped classroom approach to improving students' learning performance in a mathematics course. Computers $E$ Education, 100, 126-140. https://doi.org/10.1016/j. compedu.2016.05.006

Long, T., Logan, J. \& Waugh, M. (2016). Students' perceptions of the value of using videos as a pre-class learning experience in the flipped classroom. TechTrends, 60, 245-252. https://doi.org/10.1007/s11528-016-0045-4

Lumpkin, A. \& Achen, R. M. (2015). Flipping a class: Active learning and more of It. Sport Management Education fournal, 9, 79-90. https://doi.org/10.1123/SMEJ.2014-0042

Moen, K. M., Westlie, K., Brattli, V. H., Bjørke, L. K. \& Vaktskjold, A. (2015). Kroppsøving i Elverumskolen : en kartleggingsstudie av elever, lcerere og skoleledereres opplevelse av kroppsøvingsfaget i grunnskolen Vol. 2. Oppdragsrapport Høgskolen $i$ Hedemark Retrieved from https://brage.bibsys.no/xmlui//handle/11250/300725

Norwegian Directorate for Education and Training. (2015). Curriculum for Physical Education. (KRO1-04). Oslo Retrieved from https://www.udir.no/k106/KRO1-04/Hele/Formaal?lplang=http://data.udir.no/k106/eng.

Paris, S. G., Lipson, M. Y. \& Wixson, K. K. (1983). Becoming a strategic reader. Contemporary Educational Psychology, 8(3), 293-316.

Rikard, L. G. \& Banville, D. (2006). High school student attitudes about physical education. Sport, Education and Society, 11, 385-400. https://doi.org/10.1080/13573320600924882

Segolsson, M. \& Bäcklund, J. (2016). Flippa mellan skolämnen: En forskningsstudie om Flippad undervisning i skolår 6 och 7. Retrieved from http://www.diva-portal.org/smash/get/diva2:952886/FULLTEXT01.pdf

Statistics Norway. (2016). Marks, lower secondary school, 2016. Retrieved from https://www.ssb.no/en/ utdanning/statistikker/kargrs

Stormoen, S., Urke, H. B., Tjomsland, H. E., Wold, B. \& Diseth, Å. (2016). High school physical education. European Physical Education Review, 22, 355-371. https:/doi.org/10.1177/1356336X15612023

Säfvenbom, R., Haugen, T. \& Bulie, M. (2014). Attitudes toward and motivation for PE: Who collects the benefits of the subject? Physical Education and Sport Pedagogy, 20, 629-646. https://doi.org/10.1080/1740 8989.2014.892063

Thomas, K. T., Lee, A. M. \& Thomas, J. R. (2008). Physical education methods for elementary teachers (3rd ed. ed.). Champaign, IL: Human Kinetics.

Thompson, G. A. \& Ayers, S. F. (2015). Measuring student engagement in a flipped athletic training classroom. Athletic Training Education Fournal, 10, 315-322. https://doi.org/10.4085/1004315 


\section{Can flipped learning enhance adolescents' motivation in physical education?}

Valley, J. A. \& Graber, K. C. (2014). An examination of gender-biased communication in physical education. Research Quarterly for Exercise and Sport, Supp. Supplement, 85(S1), A160.

Vlieghe, J. (2013). Physical education beyond sportification and biopolitics: An untimely defense of Swedish gymnastics. Sport, Education and Society, 18, 277-291. https://doi.org/10.1080/13573322.2011.566602

West, S. G., Finch, J. F. \& Curran, P. J. (1995). Structural equation models with nonnormal variables: Problems and remedies. In R. Hoyle (Ed.), Structural equation modeling: Concepts, issues and applications (pp. 56-75). Newbery Park, CA: Sage.

Wigfield, A. (1994). Expectancy-value theory of achievement motivation: A developmental perspective. Educational Psychology Review, 6, 49-78. https://doi.org/10.1007/bf02209024

Wigfield, A. (2000). Facilitating children's reading motivation. In L. Baker, M.J. Dreher \& J.T. Guthrie (Eds.), Engaging young readers: Promoting achievement and motivation (pp. 140-158). New York, NY: Guilford Press.

Wigfield, A. \& Eccles, J. S. (2000). Expectancy-value theory of achievement motivation. Contemporary Educational Psychology, 25, 68-81. https://doi.org/10.1006/ceps.1999.1015

Wigfield, A., Eccles, J. S., Yoon, K. S., Harold, R. D., Arbreton, A. J., Freedman-Doan, C. \& Blumenfeld, P. C. (1997). Change in children's competence beliefs and subjective task values across the elementary school years: A 3-year study. Fournal of Educational Psychology, 89, 451-469.

World Health Organization [WHO]. (2010). Global recommendations on physical activity for health. Retrieved from http://www.cdc.gov/physicalactivity/downloads/pa_state_indicator_report_2014.pdf

World Health Organization [WHO]. (2016). Physical activity strategy for the WHO European Region 2016-2025. Retrieved from https:/www.dgs.pt/ficheiros-de-upload-2013/pnpaf-who-eu-physical-activity-strategy-2016-2025-final-2016-pdf.aspx.

Xiang, P., McBride, R. \& Bruene, A. (2004). Fourth graders' motivation in an elementary physical education running program. The Elementary School fournal, 104, 253-266. https://doi.org/10.1086/499752

Xiang, P., McBride, R. \& Bruene, A. (2006). Fourth-grade students' motivational changes in an elementary physical education running program. Research Quarterly for Exercise and Sport, 77, 195-207. https://doi.or g/10.1080/02701367.2006.10599354

Xiang, P., McBride, R. \& Guan, J. (2004). Children's motivation in elementary physical education: A longitudinal study. Research Quarterly for Exercise and Sport, 75, 71-80. https://doi.org/10.1080/02701367.2004. 10609135

Xiang, P., McBride, R., Guan, J. \& Solmon, M. (2003). Children's motivation in elementary physical education: An expectancy-value model of achievement choice. Research Quarterly for Exercise and Sport, 74, 25-35. https://doi.org/10.1080/02701367.2003.10609061

Zainuddin, Z. \& Halili, S. H. (2016). Flipped classroom research and trends from different fields of study. The International Review of Research in Open and Distributed Learning, 17, 313-340.

Zhang, H. (2016). Research on innovation of physical education teaching method based on inquiry teaching: A survey based on online questionnaire. International fournal of Future Generation Communication and Networking, 9, 37-48. https://doi.org/10.14257/ijfgcn.2016.9.2.05

Zhu, X. \& Chen, A. (2010). Adolescent expectancy-value motivation and learning: A disconnected case in physical education. Learning and Individual Differences, 20, 512-516. https://doi.org/10.1016/j. lindif.2010.04.013

Zhu, X., Sun, H., Chen, A. \& Ennis, C. (2012). Measurement invariance of expectancy-value questionnaire in physical education. Measurement in Physical Education and Exercise Science, 16, 41-54. https://doi.org/10.1 080/1091367X.2012.639629

Østerlie, O. (2016). Flipped learning in physical education: Why and how? In D. Novak, B. Antala, \& D. Knjaz (Eds.), Physical education and new technologies (pp. 166-176). Zagreb: Croatian Kinesiology Association.

Østerlie, O., Løhre, A. \& Haugan, G. The expectancy-value questionnaire in physical education: A validation study among Norwegian adolescents. Scandinavian fournal of Educational Research. 